\title{
INTUISI SEBAGAI SUMBER PENGETAHUAN: Tinjauan terhadap Pandangan Filosof Islam
}

\author{
Bambang Irawan \\ Institut Agama Islam Negeri (IAIN) Sumatera Utara \\ e-mail: bambang_irawan@yahoo.com
}

\begin{abstract}
The Islamic philosophers believe that Islam has a main pillar in the search for truth (epistemology), one of which is intuition. Aspects of Islamic epistemology can be used as an alternative in this modern era where most human hegemony has been dominated by the paradigm of positivistic scienceempiricism and western culture and sekularistik materialitik. Philosophy of western knowledge that only assess the validity of the science that is purely inductive-empirical, rational-deductive, and pragmatic, considered to have been denying or rejecting science non-empirical and non-positivism. This causes acute problems. Because at the time of this paradigm managed to find a disciplinary branch of science, discovery often reduce a reality to be just a collection of facts and material. Departing from concerns that the writer through a simple work explores the views of Sufi-related urgency intuition in generating knowledge.
\end{abstract}

Abstrak: Para filosof Islam meyakini bahwa Islam memiliki sejumlah pilar utama dalam pencarian kebenaran (epistemologi), salah satunya adalah intuisi. Aspek epistemologi Islam ini dapat dijadikan sebagai alternatif di jaman modern ini dimana kebanyakan manusianya telah dikuasai oleh hegemoni paradigma ilmu pengetahuan positivistic-empirisme dan budaya barat yang materialitik dan sekularistik. Filsafat pengetahuan barat yang hanya menilai keabsahan ilmu pengetahuan semata-mata yang bersifat induktif-empiris, rasional-deduktif, dan pragmatis, dianggap telah menafikan atau menolak ilmu pengetahuan non-empiris dan nonpositivisme. Hal ini menyebabkan persoalan yang akut. Karena pada saat paradigma ini berhasil menemukan cabang disiplin suatu ilmu, maka penemuannya sering mereduksi sebuah kenyataan menjadi hanya kumpulan fakta dan bersifat material. Berangkat dari kekhawatiran itulah penulis lewat 
BAMBANG IRAWAN:Intuisi sebagai Sumber Pengetahuan

karya yang sederhana mengeksplorasi pandangan para sufi terkait urgensi intuisi dalam menghasilkan ilmu pengetahuan.

Keywords:intuisi, filosof Islam, idealisme, rasionalisme.

\section{A. Pendahuluan}

Semua orang mengakui memiliki pengetahuan. Persoalannya dari mana pengetahuan itu diperoleh atau lewat apa pengetahuan itu didapat. Dari sinilah timbul pertanyaan bagaimana caranya kita memperoleh pengetahuan atau dari mana sumber pengetahuan kita? Pengetahuan yang ada pada kita diperoleh dengan menggunakan berbagai alat yang merupakan sumber pengetahuan itu sendiri.Dasar-dasar pengembangan ilmu pengetahuan ilmiah secara sistematis sesungguhnya telah diletakkan oleh para filosof Yunani seperti Socrates, Plato, dan Aristoteles serta filsuf lainnya sejak abad kelima sebelum Masehi. ${ }^{1}$ Pendekatan penelitian yang digunakan oleh Plato adalah apa yang dikenal ilmuwan sekarang sebagai idealisme atau rasionalisme. ${ }^{2}$ Melalui pendekatan ini pengetahuan ilmiah diperoleh secara deduktif yakni membangun konklusi umum dengan mengandalkan ide-ide murni, akal dan logika dan kemudian menerapkannya pada kasus-kasus tertentu. Pendekatan tersebut telah melahirkan alat bantu pengetahuan ilmiah berupa matematika. $^{3}$

Sementara itu Aristoeles meletakkan dasar-dasar pengembangan ilmu pengetahuan ilmiah melalui pendekatan empiris dengan mengandalkan pada kemampuan indera terutama mata dan telinga. Pendekatan ini kemudian dikenal dengan istilah metode empirisme atau metode induktif. Dalam hal ini, pengetahuan ilmiah diperoleh dengan cara mengambil konklusi umum atau generalisasi dari sejumlah kejadian baik fenomena alam maupun sosial yang bersifat kasuistik. Pendekatan empirisme atau metode induktif tersebut telah melahirkan alat bantu ilmu pengetahuan ilmiah yang disebut statistika. ${ }^{4}$ Dalam perjalanan sejarahnya, kedua pendekatan 
tersebut pernah terjadi ketidakharmonisan atau tidak seiring sejalan, karena satu dengan yang lainnya memang saling bertolak belakang, yang satu berangkat dari dunia ide, yang lain berangkat dari dunia empiris. ${ }^{5}$

Dalam perkembangan selanjutnya corak berpikir yang dikembangkan oleh filosof tertentu sangat bergantung kepada bentuk epistemologinya karena epistemologi selain sebagai bagian filsafat yang mengkaji segala sesuatu yang terkait dengan pengetahuan, seperti dasar, sifat, jenis-jenis, objek, struktur, asal mula, metode dan validitas ilmu pengetahuan ${ }^{6}$, juga merupakan struktur yang membentuk analisa filosofis yang dikembangkan oleh sang filosof.

Seperti diketahui bahwa filsafat ilmu Barat memandang ilmu (sains) hanya terbatas pada bidang empiris atau fisik. Berbeda dengan epistemologi Islam yang memandang bahwa manusia tidak hanya dapat mengetahui hal-hal yang fisik, tetapi juga yang metafisik. Perbedaan cara pandang (Barat dan Islam) dalam meneliti objek pengetahuan tersebut tentu saja melahirkan konsekuensi pada perbedaan ragam sumber ataupun sistem epistemologi yang digunakan.

Berikut ini penulis akan mengeksplorasi pandangan para sufi tentang intuisi sebagai salah satu sumber fundamental dalam memperoleh pengetahuan.

\section{B. Aliran-aliran dalam Filsafat Islam}

Sebelum penulis lebih membahas tentang urgensi intuisi dalam memperoleh pengetahuan, berikut ini akan dibahas terlebih dahulu aliran-aliran filsafat yang sangat populer didalam sejarah pemikiran filsafat Islam. Aliran-aliran tersebut sebagai berikut:

\section{Aliran Peripatetik}

Istilah peripatetik berasal dari sebuah kata Yunani (peripatos) yang berarti berjalan mondar mandir. ${ }^{7}$ Kita mengenal beberap filosof 
BAMBANG IRAWAN:Intuisi sebagai Sumber Pengetahuan

Muslim ang dikategorikan menganut aliran paripatetik, yaitu alKindī(w.866), Al-Farabi (w.950), Ibn Sina (w.1037), Ibn Rusyd (w.1196), dan Nāṣir al-Dīn Ṭūsīi (w.1274). ${ }^{8}$

Dari sudut metodologis atau epistemologis aliran parepatetik ini bisa dikenali dalam beberapa hal: (1) modus ekspresi atau penjelasan para filosof paripatetik bersifat sangat diskursif (baḥsi), yaitu menggunakan logika formal yang didasarkan pada penalaran akal. Prosedur penalaran yang mereka gunakan adalah apa yang dikenal dalam istilah filsafatsebagai silogisme, yaitu metode penarikan kesimpulan dari pengetahuan yang telah diketahui dengan baik, yang mereka sebut premis (mayor dan minor), dan setelah ditemukan term yang mengantarai dua premis di atas yang biasa disebut "middle term" atau al-hadd al-wasaț. (2) konsekuensi dari sifatnya yang diskursif, maka filsafat yang dikembangkan kaum peripatetik bersifat tak langsung. Dikatakan tak langsung karena untuk menangkap objeknya mereka menggunakan simbol, baik berupa kata-kata atau konsep maupun representasi. Modus pengetahuan seperti ini biasa disebut Hușūlī(perolehan); yakni diperoleh secara tidak langsung atau melalui representasi, dan biasanya dikontraskan dengan modus pengenalan lain yang disebut dengan ilmu Huḍūrī, yang menangkap objeknya secara langsung melalui kehadiran. (3) Ciri lain dari filsafat paripatetik dari sudut metodologis ini adalah penekanan yang sangat kuat pada daya-daya rasio sehingga kurang memprioritaskan pengenalan intuitif, sebagaimana yang dikenal dalam aliran lain, seperti Isyraqy (Iluminasionis) maupun 'irfani (gnostik). ${ }^{9}$ Karakteristik lain dari aliran paripatetik ini berkaitan dengan aspek ontologis. Hal ini dapat dilihat misalnya dalam ajaran mereka yang biasa disebut hylomorfisme, yaitu ajaran yang mengatakan bahwa apapun yang ada di dunia ini terdiri atas dua unsur utamanya yaitu materi (al-hayula) dan bentuk (șūrah). 
Dalam sejarah filsafat, ajaran ini dirumuskan dengan jelas oleh Aristoteles, sebagai hasil reformasi terhadap ajaran gurunya, Plato, yang mengatakan bahwa apa yang ada di dunia ini tidak lain dari pada bayang-bayang dari ide-ide yang ada di dunia atas -yang kemudian biasa disebut ide-ide Plato. Ide-ide ini direformulasikan Aristoteles sebagai bentuk, dan bayang-bayangnya sebagai materi. Tetapi yang dimaksud dengan bentuk di sini bukanlah bentuk fisik, melainkan semacam esensi (hakikat) dari sesuatu, sedangkan materi adalah bahan, yang tidak akan mewujud (atau muncul dalam bentuk aktualitas) kecuali setelah bergabung dengan bentuk tadi. ${ }^{10}$

\section{Aliran Iluminasionis}

Perpaduan menarik antara tradisi mistis dan filsafat paripatetik digagas oleh Suhrawardi al-Maqtul (549-587 H/1154$1191 \mathrm{M})^{11}$, konseptor aliran Isyraqi atau filsafat iluminasi. ${ }^{12}$ Dia melihat pengetahuan sejati terjadi saat kita diiluminasi (teriluminasi) oleh Sumber Cahaya dan sumber relitas realitas itu sendiri. ${ }^{13}$ Pada dasarnya, hal ini tidak bertolak belakang dengan filsafat paripatetik yang diterimanya sebagai pendekatan sahih terhadap pengetahuan konseptual meskipun kemudian membatasi bentuk pengetahuan pada yang konseptual semata, dan yang patut diingat adalah bahwa Suhrawardi mengkritisi berbagai aspek Aristotelianisme dengan kaidah-kaidah logika. Filsafat iluminasi sanggup bergerak lebih jauh melampaui filsafat paripatetik dengan menyertakan pembuktian dan menyiapkan pengetahuan langsung yang sempurna. ${ }^{14}$

Sebagai salah satu aliran filsafat Islam, filsafat iluminasi tentu memiliki beberapa karakteristik yang membedakannya dengan aliran-aliran yang lain, ditinjau dari sudut metodologis, ontologis, dan kosmologis. ${ }^{15}$

Disini terbukti bahwa karya Suhrawardi tesebut merupakan sebuah sintesis yang sangat brilian. Menurut Suhrawardi, Tuhan adalah Cahaya, sebagai satu-satunya realitas yang sejati. Ketika 
BAMBANG IRAWAN:Intuisi sebagai Sumber Pengetahuan

dihubungkan dengan cahaya-cahaya lain, Tuhan adalah cahaya di atas cahaya, sumber dari segala cahaya, darimana semua cahaya lainnya berasal atau memancar. ${ }^{16}$

Syaikh Isyraq beranggapan bahwa metode demonstratif dengan akal (burhān, demonstrative proof) dan metode intuitif ('irfānī, gnosis) ${ }^{17}$ merupakan dua metode yang pasti dalam mencerap objek eksternal, kebenaran, dan pengetahuan Haqīqū. Akal dan indera itu dipandang olehnya sebagai alat persepsi dan ia membagi ilmu menjadi hușūlī dan hựūrī. Ilmu terhadap diri sendiri ia kategorikan sebagai pengetahuan hụụ̄rīi. ${ }^{18}$

\section{Aliran 'Irfani (Tasawuf)}

Aliran 'irfani, atau tasawuf dalam istilah lainnya, sering tidak dikategorikan ke dalam aliran filsafat. Hal ini didasari oleh pandangan bahwa filsafat dalam kegiatannya bertumpu pada penalaran rasional, sementara tasawuf bertumpu pada pengalaman mistik yang bersifat supra-rasional. ${ }^{19}$ Dua cabang ilmu Islam (ilmu kalam dan tasawuf) yang bersifat naqliyah tersebut, kini telah bergeser ke wilayah 'aqliyah. ${ }^{20}$ Demikianlah, setelah masa Nashir alDin Thusi, kita melihat beberapa filosof Muslim seperti Haidar Amuli, Afdhal al-Din al-Kasyani dan Ibn Turkah, berusaha keras mensintesiskan antara filsafat dan tasawuf dan hasilnya adalah, seperti yang akan kita bahas pada fasal berikutnya.

Aliran-aliran yang beragam dalam dunia Sufisme atau Irfan memiliki kesatuan pandangan dalam permasalahan yang esensial dan substansial ini dimana mereka menyatakan bahwa pencapaian dan perolehan hakikat segala sesuatu hanya dengan metode intuisi mistikal dan penitian jalan-jalan pensucian jiwa, bukan dengan penalaran dan argumentasi rasional, karena hakikat suatu makrifat dan pengetahuan adalah menyelami dan meraih hakikat segala sesuatu lewat jalur penyingkapan, penyaksian, intuisi hati, manifestasi-manifestasi batin, dan penyaksian alam metafisika atau alam 
nonmateri dengan mata batin serta penyatuan dengannya. Dengan ungkapan lain, yang lebih mendasar dan fundamental dalam hakikat pengetahuan dan makrifat adalah pensucian jiwa dan tazkiyah hati, dan bukan dengan analisa pikiran dan demonstrasi rasional. ${ }^{21}$

Dalam pandangan Ibn Arabi, akal tidak mampu mencerap objek-objek eksternal secara langsung, oleh karena itu akal sangat membutuhkan indera-indera lahiriah, sementara indera-indera itu juga dipengaruhi oleh karakter dan keadaan alaminya masingmasing yang tidak dapat mempersepsi realitas-realitas nonmateri. Dengan demikian, dengan perantaraan akal, manusia tidak akan mungkin menyingkap dan memahami hakikat-hakikat dan batinbatin alam. ${ }^{22}$ Lebih lanjut dia menyatakan, "Kesalahan para filosof adalah karena memandang bahwa indera-indera itu melakukan kekeliruan, padahal dalam hal ini, akallah yang melakukan kesalahan, bukan persepsi inderawi. ${ }^{23}$ Perspesi-persepsi akal itu terbagi dua bagian: 1) Persepsi aksioma yang pasti (dimana tidak akan mengalami kesalahan); 2) Persepsi non-aksioma yang tak pasti (persepsi ini berhubungan dengan daya pikir dan indera-indera lahiriah, persepsi jenis inilah yang terkadang menimbulkan suatu kesalahan dan kekeliruan). ${ }^{24}$

\section{Aliran Hikmah Muta'aliyah}

Dalam sejarah peradaban filsafat Islam, Mulla Șadrā adalah tokoh filsafat muslim yang diakui sebagai orang yang paling berjasa bagi lahirnya Filsafat Hikmah. ${ }^{25}$ Bahkan dengan filsafat hikmah ini, Mulla Șadrā dikenal sebagai tokoh yang yang membangun aliran filsafat baru untuk mempertemukan berbagai aliran pemikiran yang berkembang di kalangan kaum muslim. Yakni tradisi Aristotelian cum neoplatonis yang diwakili al-Faraby dan ibnu Shina, filsafat iluministik, irfaninya Ibnu 'Arabi serta tradisi kalam (teologi) yang pada waktu telah mencapai tahap filosofisnya melalui figur Nāṣir alDīn al-Ṭūsī (1273 M). ${ }^{26}$ 
BAMBANG IRAWAN:Intuisi sebagai Sumber Pengetahuan

Secara epistemologis, filsafat hikmah atau yang lebih populer dikenal dengan Hikmatul Muta'aliyah ini bertumpu pada tiga sumber pengetahuan yaitu intuisi intelektual (intuitif atau dzauq), pembuktian rasional ('aqliatau istidlāl) dan syari'at. ${ }^{27}$ Adapun secara ontologis, filsafat Hikmah ini berdasar pada tiga hal yaitu: realitas wujud (așlah al-wujūd), ambiguitas wujud (tasyqīq al-wujūd) dan gerak substansial (harakat al-jauhariyah). ${ }^{28}$ Dalam ketiga kerangka pokok inilah secara aksiologis, Șadrā berusaha menjawab masalah realitas mahiyah (kuiditas atau esensi), dan wujud (eksistensi) yang menyusun setiap maujud. ${ }^{29}$ Dalam kaitannya dengan ilmu, Mulla Șadrā mengatakan bahwa mustahil mendefinisikan ilmu itu, karena tidak ada yang lebih jelas daripada ilmu yang dengannya ia terdefinisikan. ${ }^{30}$

Mulla Sadra membagi konsep-konsep universal itu menjadi kuiditas (mahiyah), filosofis, logikal. ${ }^{31}$ Apakah konsep-konsep kedua filosofis ini bersifat haqīqi atau majasi? Ia menyatakan bahwa konsep-konsep ini merupakan ungkapan dari tingkatan-tingkatan wujud eksternal, dimana setiap maujud yang lemah, pancaran dan pengungkapannya pun akan lemah dan berada pada batas "kemungkinan" untuk dicerap oleh akal. ${ }^{32}$

Pembahasan lain yang dijabarkan Mulla Sadra ialah mengenai wujud pikiran. ${ }^{33}$ Materi ini ia jelaskan secara terperinci. ${ }^{34}$ Dalam kajian tentang wujud pikiran ini, ditegaskan tentang kesatuan kuiditas objek pikiran dan objek eksternal dimana hal ini sangat ampuh menyelesaikan persoalan rumit mengenai kesesuaian ilmu manusia dengan objek-objek eksternal. ${ }^{35}$ Mulla Sadra tetap merupakan tokoh yang sangat berpengaruh dalam kelanjutan tradisi filsafat Islam sampai sekarang ini. Meski diakui pemikirannya bukanlah satu-satunya yang memiliki pengikut, ternyata ajaran Mulla Sadra mampu berdampingan dengan filsafat peripatetik-Ibnu Sina dan iluminasi-Suhrawardi. Mulla Sadra mempunyai banyak murid dan pengikut, di antaranya Mulla Ali al-Nuri, al-Sabzarawi dan 
BAMBANG IRAWAN:Intuisi sebagai Sumber Pengetahuan

al-Qumsyeh'i, Abd. al-Razaq Lahiji dan Muhsin Faid Kasyani. Dengan demikian, filsafat aliran Hikmah al-Muta'aliyah Mulla Sadra tidak hanya berpengaruh pada dunia pemikiran filsafat Islam di Iran, tetapi juga berkembang terus karena peran murid dan penerusnya sampai dinasti berikutnya. ${ }^{36}$

Dari penjabaran epistemologi aliran Hikmah Muta'aliyah yang diwakili oleh Mulla sadra diatas dapat kita simpulkan bahwa dalam epistemologinya bergabung tradisi paripatetik, irfan, dan iluminisme, sekaligus teologi dan tradisi Islam. Demikianlah sampai sekarang filsafat hikmah terus berkembang dengan baik, khususnya di Persia dan Anak Benua India.

\section{Intuisi dan Urgensinya dalam Memperoleh Penge- tahuan}

Ibn Sina menyebut intuisi dengan al-hads| al-qudsī|intuisi suci). ${ }^{37}$ Berbeda dengan pengetahuan rasional, pengenalan intuitif disebut juga hụūūrī, karena objek penelitiannya hadir dalam jiwa penelitinya $^{38}$, sehingga ia menjadi satu dan identik dengannya. Di sinilah hubungan antara subjek dan objek terjembatani sehingga tidak menimbulkam jurang atau jarak antara subjek dan objek. Karena kesatuan yang tercapai dalam modus pengetahuan intuitif antar subjek (al-'alim) dan objek (al-ma'lum), seseorang akan mengetahui secara langsung dan akrab dengan objek yang sedang ditelitinya tanpa melalui konsep-konsep atau representasi apapun. ${ }^{39}$

Dalam kitabnya Nihāyah al-Hikmah dan Bidāyah al-Hikmah, Thabathabai banyak menjelaskan berbagai persoalan metafisik dan mengeksplorasi metode intuitif dalam memperoleh pengetahuan. Pembahasan-pembahasan yang dimaksud mencakup: ilmu ḥuḍūrī, ilmu badīhī, teori kesatuan subjek dan objek pengetahuan, eksistensi mental, emanasi, alam mis $\mid \overline{a l}$, pengetahuan Tuhan. ${ }^{40}$

Berkaitan dengan intuisi, yang lebih mendasar dan fundamental dalam meraih hakikat pengetahuan adalah pensucian jiwa 
BAMBANG IRAWAN:Intuisi sebagai Sumber Pengetahuan

dan tazkiyah hati, dan bukan dengan analisa pikiran dan demonstrasi rasional. ${ }^{41}$ Para urafa dan sufi beranggapan bahwa segala pengetahuan yang bersumber dari intuisi-intuisi, musyāhadah, dan mukasyafah lebih sesuai dengan kebenaran daripada ilmu-ilmu yang digali dari argumentasi-argumentasi rasional dan akal. Mereka menyatakan bahwa indera-indera manusia dan fakultas akalnya hanya menyentuh wilayah lahiriah alam dan manifestasi-manifestasi-Nya, namun manusia dapat berhubungan secara langsung (directly) dan intuitif dengan hakikat tunggal alam (baca: Sang Pencipta) melalui dimensi-dimensi batiniahnya sendiri dan hal ini akan sangat berpengaruh ketika manusia telah suci, lepas, dan jauh dari segala bentuk ikatan-ikatan dan ketergantungan-ketergantungan lahiriah. ${ }^{42}$ Pengetahuan seperti ini tidak dapat disamakan dengan pengetahuan ḥuṣūlìyang bersumber dari suatu konsepsikonsepsi rasional, melainkan suatu pengetahuan syuhūdī, intuisi, immediate (langsung), kehadiran, dan ḥuḍūrī. ${ }^{43}$

Dengan demikian, intuisi bisa melengkapi pengetahuan rasional dan inderawi sebagai suatu kesatuan sumber ilmu yang dimiliki manusia, dan memberi banyak tambahan informasi yang lebih akrab dan partikular tentang sebuah objek dengan cara yang berbeda dengan yang ditempuh oleh akal maupun indera. ${ }^{44}$

Terkait dengan pemilahan ilmu yang diperoleh melalui indera atau akal (bahs $\mid i)$ dan melalui intuisi (||z|auqī), Suhrawardi menyebut tiga macam kemampuan manusia, pertama, ada yang seperti para sufi yakni memiliki pengalaman $z \mid a u q \bar{i}$ yang sangat dalam, tetapi tidak mampu mengungkapkannya dalam bahasa filosofis yang diskursif. Kedua, kalangan filosof yang mempunyai kemampuan mengekspresikan pikiran-pikiran mereka secara filosofis-diskursif, tetapi tidak memiliki pengalaman mistik yang mendalam. Ketiga, para muta'allih, yang memiliki pengalaman mistik yang mendalam seperti para sufi, tetapi juga punya kemampuan bahasa filosofis yang diskursif seperti yang dimiliki para filosof. 
Kelompok yang ketiga inilah yang dinilai Suhrawardi sebagai kelompok tertinggi diantara para pencari kebenaran. ${ }^{45}$

Penjelasan mengenai sumber pengetahuan dalam Islam pada umumnya dan epistemologi khususnya dengan demikian lebih komprehensif dan menyeluruh; bahwa sekalipun secara sepintas tampak ada persamaan-persamaan antara uraian filsafat Barat dan Islam, namun hal itu tidak menegasikan perbedaan-perbedaan fundamental antar keduanya.

\section{Eksistensi Jiwa; Pintu Masuk Pengetahuan Intuitif}

Para sufi diakui telah memberikan andil yang sangat besar dalam mengembangkan kajian tentang kejiwaan. sayangnya, peranan mereka dalam memajukan dan mengembangkan ilmu kejiwaan (psikologi) tersebut tidak mendapatkan perhatian yang selayaknya dari para pakar sejarah psikologi modern sepanjang sejarah. Umumnya mereka yang berasal dari Barat memulai kajian psikologi pada kaum pemikir Yunani, terutama Plato dan Aristoteles. Selanjutnya mereka merujuk pemikiran kejiwaan dari para pemikir Eropa Abad pertengahan dan Eropa Modern. Mereka benar-benar melupakan andil para ilmuwan Muslim yang diantaranya banyak diterjemahkan ke dalam bahasa Latin dan banyak mempengaruhi pendpat para pemikir Eropa Abad pertengahan hingga awal masa Renaisans Eropa Modern sendiri. ${ }^{46}$

Al-Kindi yang mengatakan bahwa pengetahuan tentang hakikat segala sesuatu, tidak diperoleh melalui alat indera, tetapi dapat dicapai melalui emanasi Allah SWT.47 Cara mendapatkannya adalah dengan penyucian jiwa dari berbagai noda kehidupan yang materialistik dan syahwat duniawi serta menyibukkan diri dengan menganalsis dan meneliti hakikat segala sesuatu sehingga menjadi siap untuk menerima emanasi pengetahuan dari Allah SWT. Penulis menyimpulkan bahwa al-Kindi memiliki dasar ide tentang kasyaf yang didengungkan para sufi dikemudian hari. ${ }^{48}$ 
BAMBANG IRAWAN:Intuisi sebagai Sumber Pengetahuan

Hampir senada dengan al-Farabi yang berpandangan bahwa tujuan akhir dari akal manusia adalah kebersambungan dengan akal yang terpisah dan mengidentikkan diri dengannya. Artinya bahwa, pengetahuan yaqiniyah tidak akan dapat dicapai kecuali melalui emanasi yang berasal dari Akal Aktif (Allah) sebagai pemberi pengetahuan dan pemberi gambar-gambar. Oleh karena itu al-Farabi menyebutnya ma'rifah isyrāqiyah (pengetahuan iluminatif). ${ }^{49}$

Demikian pula pandangan Ibnu Sina tentang teori pengetahuan. Menurutnya persepsi inderawi merupakan tahap pertama dan pembuka yang menyiapkan jiwa bagi pengetahuan rasional yang sebenarnya tidak diperoleh melalui jalur inderawi, tetapi diperoleh melalui jalur di luar akal manusia, yaitu jalur ilham dan emanasi dari Akal Aktif, yakni akal yang terpisah dari materi. ${ }^{50}$

Kematangan logika yang dibangun al-Farabi juga dapat menghilangkan keraguan seputar ilmu Allah. Wacana tentang ilmu Allah ini merupakan satu dari banyak persoalan yang diperdebatkan oleh dua filosof terkemuka yang mewakili filosof Timur (Abu Hamid al-Ghazali) dan filosof Andalusia (Ibn Rusyd). Meminjam konsep "keterputusan epistemologis" (al-qați'ah al-ibistimulujiyah) antara pemikiran Islam di wilayah Timur dan wilayah Barat, penyebutan nama Al-Kindi dan Al-Farabi sebagai mata rantai pendekatan filsafat menandai berkembangnya rasionalisme di wilayah Timur (meski tidak dipungkiri tentang pengadopsian al-Farabi terhadap teori emanasi yang memunculkan klaim sebagi pengikut neo-Platonik. Sedangkan mata rantai pendekatan filsafat di wilayah Barat dapat ditelusuri dalam pemikiran Ibn Bajjah, Ibn Rusyd, al-Syatibi dan Ibn Khaldun, dan lain-lain.

Seirama dengan pendapat Ibnu Tufail dalam memperoleh pengetahuan. Ia berpandangan bahwa pengetahuan dapat diperoleh melalui melaui dua jalan, pertama, melalui indera, pengalaman, dan penalaran rasional. Kedua, jalan tasawuf. Menurutnya pengetahuan 
BAMBANG IRAWAN:Intuisi sebagai Sumber Pengetahuan

dapat dicapai manusia melalui jalan kasyaf șufi atau melalui jalan wahyu. ${ }^{51}$

Dalam perspektif filosofis, Tuhan tidak bisa secara langsung menciptakan alam yang tak terhingga jumlah unsur-unsurnya ini. Sebab, kalau Tuhan berhubungan langsung dengan alam yang jamak ini, bisa menyebabkan rusaknya citra tauhid dalam diri Tuhan. Oleh sebab itu agar ketauhidan tetap terjaga, harus dipahami bahwa alam semesta yang tersusun dari banyak bagian ini diciptakan oleh Allah SWT secara emanasi, dalam arti bahwa wujud allah melimpahkan wujud alam secara tidak langsung. ${ }^{52}$

Untuk tujuan tersebut maka Ibn Sina menetapkan adanya perantara, yaitu berupa akal-akal antara Allah yang Maha Esa dan alam yang beraneka ragam ini. Hal ini agar yang banyak tesebut dapat melimpah, terutama yang berkaitan dengan materi-materi lain. Karena Allah adalah akal murni yang tidak mungkin melimpah dariNya yang berbentuk dan berubah. ${ }^{53}$

Sadruddin Qunawi menyatakan, "Jalan-jalanya ahli Irfan dan Tasawuf adalah mencapai, mengetahui, dan menyaksikan segala sesuatu dengan intuisi, musyāhadah, dan mukasyafah, walaupun halhal yang diketahuinya itu tidak dapat diargumentasikan secara rasional dan tak bisa dibuktikan dengan penalaran akal-pikiran'. Bahkan ia beranggapan bahwa makrifat dan pengetahuan haqīqi adalah yang bersifat syuhudi dan intuitif, dan akal sama sekali tidak mampu menyingkap dan menggapai hakikat-hakikat segala sesuatu dan realitas-realitas metafisikal. ${ }^{54}$

Mereka berkeyakinan bahwa daya akal itu sama posisinya dengan indera-indera lahiriah yang hanya terbatas menjangkau ranah-ranah lahiriah alam dan penampakan-penampakan eksternal segala sesuatu. Manusia dapat mencapai hakikat-hakikat alam dan mencerap realitas-realitas metasikal serta pengetahuan huḍūrī dengan metode intuisi dan meninggalkan segala bentuk keterikatan 
BAMBANG IRAWAN:Intuisi sebagai Sumber Pengetahuan

kepada dimensi-dimensi lahiriah dan kebutuhan-kebutuhan duniawi.

Menurut mereka segala makrifat dan pengetahuan yang bersumber dari intuisi-intuisi, musyahadah, dan mukasyafah lebih sesuai dengan kebenaran daripada ilmu-ilmu yang digali dari argumentasi-argumentasi rasional dan akal. Mereka menyatakan bahwa indera-indera manusia dan fakultas akalnya hanya menyentuh wilayah lahiriah alam dan manifestasi-manifestasi-Nya, namun manusia dapat berhubungan secara langsung (directly) dan intuitif dengan hakikat tunggal alam (baca: Sang Pencipta) melalui dimensi-dimensi batiniahnya sendiri dan hal ini akan sangat berpengaruh ketika manusia telah suci, lepas, dan jauh dari segala bentuk ikatan-ikatan dan ketergantungan-ketergantungan lahiriah.

Ma'rifat, syuhūd, dan pengetahuan dalam istilah tasawuf dan 'irfan adalah penyaksian hakikat-hakikat dengan mata batin dan hati setelah melewati tingkatan-tingkatan pensucian jiwa dan telah sampai pada kualitas-kualitas kejiwaan yang konstan. Pengetahuan intuitif dan 'irfani adalah sejenis pengetahuan yang bersumber dari hati (qalb, heart), pensucian, dan tazkiyah jiwa; atau suatu bentuk pengetahuan yang tak berdasarkan pada hal-hal empirik, inderawi, akal, pikiran, dan argumentasi rasional, melainkan bersumber dari mata air syair suluk, menapaki jalan-jalan spiritual, tahzib dan tazkiyah jiwa, dan penjernihan hati. Pengetahuan seperti ini tidak dapat disamakan dengan pengetahuan hușūlìyang bersumber dari suatu konsepsi-konsepsi rasional, melainkan suatu pengetahuan syuhudi, intuisi, immediate (langsung), kehadiran dan ḥuḍ̄rīi. ${ }^{55}$

Dalam risalah Qusyairiyah tertera ungkapan yang berbunyi, "Hati adalah wadah bagi makrifat-makrifat, dan akal adalah rukun dan tiang makrifat, akan tetapi, akal telah terhijabi, lemah, dan tidak dapat menjangkau pengetahuan terhadap hakikat-hakikat segala sesuatu dan sebagainya dan pengetahuan intuisi ini akan lahir ketika 
BAMBANG IRAWAN:Intuisi sebagai Sumber Pengetahuan

langit hati telah menjadi jernih dan terang serta menerima pancaran "cahaya matahari" dari wilayah suci yang paling tinggi dan mulia."56

Dengan demikian semua aliran-aliran tasawuf itu tidak meragukan bahwa segala pengetahuan diperoleh lewat jalur musyahadah, mukasyafah dan penyingkapan hati yang kesemuanya dipengaruhi oleh bentuk riyadah dan pelaksanaan amalan-amalan sunnah (nawäfil). Begitu pula mereka berkeyakinan bahwa tidak ada ilmu dan pengetahuan yang lebih tinggi selain dari pengetahuan intuitif dan irfani. Seluruh petunjuk dan perhatian aliran ini mengarah kepada pengetahuan intuitif, ainul yaqin, ilmu hati, dan ilmu laduni yang bersumber dari pencerahan kejiwaan, kesucian hati, kekuatan ruh, mukasyafah, musyahadah hati, sair dan suluk, dan riyadhah. Pengetahuan ini juga berbeda dengan 'ilm al-yaqīn (pengetahuan yang berpijak pada pendekatan rasional dan demontrasi filosofis).

Para sufi berkeyakinan bahwa seseorang yang mata hatinya terbuka dan mendapatkan pencerahan jiwa ibarat menemukan harta karun yang nilainya tak terbatas itu (akal yang tercerahkan dan pengetahuan intuitif), merekalah orang yang tidak lagi membutuhkan ribuan kitab, merujuk pada perpustakaan, bersabar dalam penderitaan menuntut ilmu, dan tidak lagi menganggap bernilai segala pengetahuan hușūlī."57

Terkait dengan kemampuan jiwa ini, Mulla Șadrā mengatakan sebagai berikut: "Sesungguhnya Allah Ta'ala menciptakan jiwa manusia dengan menciptakan baginya kemampuan mencipta bentuk sesuatu yang non-material dan material karena merupakan bagian dari dimensi malakut dan alam kemampuan serta ketinggian. Para malaikat memiliki kemampuan untuk memunculkan bentuk-bentuk akal (șuwār al-'aqliyah) yang bersandar pada esensinya dan visual semesta yang bersandar pada materinya". ${ }^{58}$

Bukti lain tentang keistimewaan intuisi dibanding akal dapat dilihat dari sebuah karya Ibn 'Arabi yang berjudul Risālah al-Anwār fi 
BAMBANG IRAWAN:Intuisi sebagai Sumber Pengetahuan

mā Yumnah Șahib al-Halwa mina'l-Asrār. Lewat karyanya ini Ibn 'Arabi menceritakan apa yang dialaminya selama zikirnya yang intensif. Ternyata melalui zikirnya tersebut, Ibn 'Arabi dapat menembus berbagai 'dunia', baik dunia fisik maupun non-fisik. Betapa tidak, menurut pengakuannya, dalam zikirnya itu ia dibawa masuk ke dunia mineral dan diperkenalkan pada berbagai batubatuan, permata dan logam-logam dengan segala manfaatnya, baik yang bersifat medis maupun nutritif. Demikian juga ketika terus melanjutkan zikirnya, ia juga masuk ke alam tumbuhan, dimana segala macam tumbuhan memperkenalkan diri mereka beserta manfaat medis dan nutrisinya. Demikian seterusnya, ia mendapatkan pengalaman-pengalaman mistik yang memesona, seperti bisa melihat surga beserta tingkat-tingkatnya, dengan anak-anak tangganya yang indah; bahkan ia dapat melihat 'Arsy dan dunia gaib lainnya yang menakjubkan, dimana akal manusia tidak bisa berbuat apa-apa karena kebingungannya yang yang begitu dahsyat. Ada sekitar 23 dunia gaib yang diungkapkan begitu saja kepadanya, sebagaimana dapat kita baca dalam karyanya ini. Inilah pengalaman mistik yang begitu kaya yang diperoleh lewat hati (intuisi), dimana penelitian akal tidak mengambil peranan sedikitpun. ${ }^{59}$

Meskipun demikian kita diingatkan oleh Farid al-Din 'Aththar bahwa setinggi-tingginya pengalaman sufi, itu baru awal dari pengalaman spiritual para nabi. ${ }^{60}$ Baik al-Farabi maupun Ibn Sina memang mengakui tingkatan kenabian yang dialami manusia. Ada tingkatan kenabian yang lebih rendah seperti yang mungkin dialami oleh para wali atau sufi, tetapi ada juga tingkat kenabian yang lebih tinggi, seperti yang dalami oleh para nabi sendiri. Wahyu atau kenabian adalah puncak pengalaman spiritual yang dicapai oleh para Nabi, termasuk Nabi kita Muhammad SAW.

Sejalan dengan Mulla Husain Kasyani menyatakan bahwa, "Ma'rifat dan syuhūd serta segala sesuatu diliputi oleh Al-Haqq (Tuhan) secara esensial. Allah berfirman: "Dan apakah Tuhan-mu 
BAMBANG IRAWAN:Intuisi sebagai Sumber Pengetahuan

tidak cukup (bagimu) bahwa sesungguhnya Dia menyaksikan segala sesuatu?"61 Karena seorang sālik telah sampai pada maqam ketuhanan tersebut (sebagaimana firman-Nya) maka dia senantiasa "menyaksikan" cahaya-cahaya gaib dan hakikat-hakikat segala sesuatu."62

Terkait dengan masalah ini, Imam Khomeni berpandangan bahwa manusia secara fitri bersandar pada argumentasi akal dan demonstrasi rasional, yakni fitrah manusia tunduk pada dalil dan burhān akal. Itulah fitrah yang dikhususkan bagi manusia dan tidak ada perubahan dalam penciptaan Tuhan. ${ }^{63}$ Sedikitnya terdapat dua peran mendasar dari pensucian dan pencerahan jiwa yang dapat dikemukakan di sini, antara lain bahwa "kotoran" yang melekat pada hati dan jiwa merupakan penghalang bagi manusia untuk "menyaksikan" hakikat-hakikat yang terdalam dan kendala untuk mendapatkan pengetahuan yang benar. Pensucian hati bertujuan untuk menyingkirkan hijab-hijab kegelapan dan menyirnakan segala bentuk hawa nafsu, dendam, ketamakan, kezaliman, kebencian, cinta dunia, cinta kekayaan, dan cinta kekuasaan, sedemikian sehingga musnahlah segala bentuk penghalang dan musuh terbesar bagi akal dan jiwa manusia. Dan dengan lahirnya kesucian dan kecerahan batin tersebut, manusia akan mendapatkan suatu pandangan dunia baru dalam memandang dan menafsirkan realitas-realitas haqqīqī dan objek-objek eksternal. Karena kita yakin bahwa tidak semua pandangan dan perspektif filosofis terhadap alam eksistensi ini adalah benar dan mampu mengantarkan manusia pada kebahagiaan haqīqi dan keselamatan abadi. ${ }^{64}$ Maka dari itu, dalam maktab Islam, pensucian hati adalah upaya pengkondisian diri untuk menerima emanasi dan pancaran cahaya Ilahi dan usaha untuk melahirkan kemampuan diri dalam membedakan antara gagasan-gagasan yang benar dan yang batil serta memilih yang terbaik di antara konsepkonsep yang benar. Hai orang-orang yang beriman, jika kamu bertakwa kepada Allah, niscaya Dia akan memberikan kepadamu 
BAMBANG IRAWAN:Intuisi sebagai Sumber Pengetahuan

(kekuatan) pembeda (antara yang hak dan yang batil di dalam hatimu). ${ }^{65}$

Peran penting lain dari pensucian dan tazkiyah hati adalah bahwa hati dan jiwa yang telah tercerahkan akan menjadi sebagai sumber berbagai ilham-ilham dan media bagi penyingkapan hakikathakikat segala sesuatu serta sebagai tempat emanasinya berbagai makrifat-makrifat transenden dan Ilahi yang tidak mungkin dapat dicapai melalui jalan-jalan rasional dan akal. Hal ini sebagaimana yang disinyalir dalam al-Qur'an:

"Dan orang-orang yang berjihad untuk (mencari keridaan) Kami, benar-benar akan Kami tunjukkan Kepada mereka jalan-jalan Kami.66

Hai orang-orang yang beriman,bertakwalah kepada Allah dan berimanlah kepada rasul-Nya, niscaya Allah memberikan dua bagian rahmat-Nya kepadamu, menjadikan untukmu cahaya yang dapat kamu gunakan untuk berjalan, dan mengampunimu. Allah Maha Pengampun lagi Maha Penyayang." 67

Tinjauan ilmiah dan filosofis dari pensucian diri dan hati dalam perolehan beberapa rangkaian makrifat dan hikmah diutarakan oleh filosof Murtadha Muthahhari sebagai berikut: Beberapa sifat-sifat yang berpengaruh pada akal ${ }^{68}$ manusia, yakni akal praktis manusia, adalah kesombongan, fanatisme, dan sifat-sifat kejiwaan lainnya. Wilayah dan ranah akal praktis manusia dikarenakan berhubungan dengan amal dan perbuatan manusia maka niscaya pun berkaitan dengan domain perasaan, kecenderungan, dan syahwat manusia. Segala perbuatan manusia apabila telah keluar dari batasan keseimbangannya dan manusia telah sedemikian dipengaruhi oleh efek-efek negatifnya serta akal manusia telah mengikuti segala kecenderungannya secara mutlak, maka dalam kondisi seperti manusia tidak dapat lagi mendengar suara-suara dan pertimbangan akalnya sendiri. Lebih jauh dari ini, akal akan terselimuti dan 
BAMBANG IRAWAN:Intuisi sebagai Sumber Pengetahuan

terhijabi dengan kabut gelap hawa nafsu sedemikian sehingga cahayanya yang suci tidak bisa lagi terpancar untuk menerangi dan mencerahkan hati dan jiwa manusia.

\section{E. Penutup}

Dari uraian di atas dapat dipahami bahwa pensucian hati merupakan metode yang paling baik dan sempurna untuk mencapai pengetahuan intuitif, namun bukan berarti para sufi hendak menyatakan bahwa untuk mendapatkan pengetahuan tentang dunia natural, ilmu matematika, kedokteran, dan ilmu-ilmu empirik lainnya juga harus melalui metode intuisi dan pensucian hati. Yang sebenarnya adalah kedua fakultas ini saling mendukung satu sama lain, ilmuwan seperti Pascal, William James, A. Carrel, dan Albert Einsten mengakui bahwa fakultas hati itu begitu banyak mengilhami lahirnya berbagai penemuan ilmiah dan rakayasa teknologi.

Dengan demikian kita dapat membedakan pengetahuan rasional dengan dengan pengetahuan intuitif. Pengetahuan rasional atau pengetahuan yang bersumber dari akal adalah suatu pengetahuan yang dihasilkan dari proses belajar dan mengajar, diskusi ilmiah, pengkajian buku, pengajaran seorang guru, dan sekolah. Hal ini berbeda dengan pengetahuan intuitif atau pengetahuan yang berasal dari hati. Pengetahuan ini tidak akan didapatkan dari suatu proses pengajaran dan pembelajaran resmi, akan tetapi, jenis pengetahuan ini akan terwujud dalam bentukbentuk "kehadiran" dan "penyingkapan" langsung terhadap hakikathakikat yang dicapai melalui penapakan mistikal, penitian jalan-jalan keagamaan, dan penelusuran tahapan-tahapan spiritual.

Orang-orang suci yang telah mencapai maqam walāyah dan nubuwwah diyakini memiliki pengetahuan tersebut sehingga terjaga dari kesalahan ('ișmah). Secara hierarkhis, jenis pengetahuan semacam ini dianggap berada pada posisi paling tinggi dan prasyarat pemerolehannya amat bergantung pada mujāhadah dan riyādah. 
Hasil dari penalaran ini adalah ilmu-ilmu intuitif, seperti akhlak dan tasawuf. Untuk konteks zaman moden ini, para sarjana Islam, perlu mengetahui kelebihan dan kekurangan pemikiran intuitif ini dan perlu memadukannya secara integral dengan pendekatan lainnya.]

\section{Catatan Akhir}

${ }^{1}$ Oliver Leaman, Pengantar Filsafat Islam: Sebuah Pendekatan Tematis, Bandung: Mizan, 2001, h. 8. Baca juga M.M.Syarif (ed.), a History of Muslim Philoshophy, Vol I, Wiesbaden: Otto Harrassowitz, 1963, h. 346-348

2Ibrahim Madkour, Aliran dan Teori Filsafat Islam, Jakarta: Bumi Aksara, 1995, h. 118. Lihat juga Notonagoro, "Azas-azas Filsafat", diktat, Yogyakarta: Yayasan Pembinaan Fakultas Filsafat UGM, 1969.

${ }_{3}^{3}$ Harun Nasution, Falsafat Agama, Jakarta: Bulan Bintang, 1991, h. 23-51.

${ }^{4}$ Muhammad Taqi Misbah Yazdi, Philosophycal Instructions, An Introduction to Contemporary Islamic Philosophy, New York: Global Publications, 1999, h. 11.

5Mahmud Thoha, Paradigma Baru Ilmu Pengetahuan Sosial \& Humaniora, Bandung: Teraju, 2004, h. 1. Baca juga Juhaya S.Praja, Filsafat dan Metodologi Ilmu dalam Islam dan penerapannya di Indonesia, Jakarta:Teraju, 2002, h. 34-35. Lihat juga C.A Qadir, Philosophy and Science in the Islamic World, London: Routledge, 1990, h. $94-95$

${ }^{6}$ Kata epistemologi berasal dari bahasa Yunani yang berarti teori ilmu, pertama kali digunakan sebagai term untuk teori pengetahuan oleh J.F. Ferrier, filsuf scotlandia. Lihat Jalāl Muhammad al-Ḥāmid Mūsā, Manhaj al-Baḥs al-'Ilm 'inda al-'Arab, Beirūt: Dār al-Kutub alLubnani, 1972, h. 33.

${ }^{7}$ Haidar Bagir, Buku Saku Filsafat Islam,Bandung : Mizan, 2010, h. 93.

8Mulyadi Kartanegara, Gerbang Kearifan: Sebuah Pengantar Filsafat Islam, Jakarta: Lentera Hati, 2006, h. 27.

9Ibid., h. 27-29.

${ }^{10} \mathrm{Di}$ dunia Islam hampir semua filosoof paripatetik, seperti alKindi, al-Farabi, Ibn Sina dan Ibn Rusyd, memiliki pandangan hylomorfis ini, dan mungkin karena itu maka para filosof di atas disebut filosof Paripatetik (Masya'iyun), yang dapat dibedakan dari aliran filsafat lainnya. Indikasi yang kuat dari ajaran hylomorfis ini dapat dilihat dari ajaran para filosof paripatetik Muslim khususnya Al-Farabi 
BAMBANG IRAWAN:Intuisi sebagai Sumber Pengetahuan

dan Ibn Sina, yang menyebut akal aktif (al-'aql al-fa'al) sebagai pemberi bentuk (wahib al-șuwar). Ajaran ini mengatakan bahwa alam fisik ini terdiri atas materi dan bentuk. Materi harus dipahami disini sebagai bahan, yang potensial menerima bentuk apapun, tetapi tidak/belum lagi berbentuk fisik

${ }^{11}$ Suhrawardi dilahirkan di desa kecil, Suhraward, Persia Barat. Ia belajar di di Zanjan dan Isfahan, dimana ia belajar agama, filsafat dan sufisme. Ia kemudian pergi ke Anatolia dan singgah di Aleppo, beroposisi dengan fuqahā tertentu dan meninggal pada usia yang sangat muda.

${ }^{12}$ Kata iluminasi itu sendiri bermakna bahwa apabila kita mampu meyempurnakan diri sendiri, kita bisa mendapat iluminasi dari sumber realitas secara langsung. Suhrawardi mengganti pandangan realitas yang terdiri dari rangkaian objek dengan pandangan realitas sebagai derajat cahaya yang bertingkat Suhrawardi, The Philosophy of Illumination (Hikmah al-Isyrāq), terj. John Walbridge \& Hosein Ziai, h. 21.

${ }^{13}$ Suhrawardi, The Mystial and Visionary Treatises of Suhrawardi, terj. W.M. Thakston, h. 44-46

${ }^{14}$ Berbeda dengan aliran paripatetik, yang lebih menekankan penalaran rasional sebagai metode berpikir dan pencarian kebenaran, filsafat iluminasionis mencoba memberikan tempat yang penting bagi metode intuitif ('irfani), sebagai pendamping bagi, atau malah, dasar bagi penalaran rasional. Di sini Suhrawardi mencoba mensistesiskan dua pendekatan ini, burhani dan irfani dalam sebuah sistem pemikiran yang solid dan holistik. Baca Oliver Leaman, Pengantar Filsafat Islam, h. 11

${ }^{15}$ Pengalaman mistik adalah pengalaman langsung melihat realitas sejati, karena dalam pengalaman mistik seperti itu, "objek" penelitian telah "hadir" pada diri seseorang, sehingga modus pengenalan seperti ini sering disebut ilmu huduri (knowledge by presence) yang kemudian dibedakan dengan ilmu husuli (acquired knowledge) dimana objek penelitian diperoleh tidak secara langsung, melainkan melalui sebuah representasi, baik itu berupa simbol atau konsep. Arti penting pengalaman mistik bagi pencarian kebenaran adalah bahwa melalui pengalaman tersebut seseorang (filosof atau sufi) dapat secara langsung menyaksikan kebenaran sejati (al-Haqq), yang tidak bisa diperoleh dengan cara yang sama melalui pendekatan apapun, baik indera maupun akal. Bagaimanapun pengalaman mistik harus diuji kebenarannya lewat bahasa diskursif yang dialami pelakunya. Ketika Suhrawardi ditanya oleh muridnya apakah buku 
BAMBANG IRAWAN:Intuisi sebagai Sumber Pengetahuan

Hikmah al-Isyraq merupakan karya mistik atau filsafat, Suhrawadi menjawab bahwa bukunya tersebut adalah kitab filsafat yang didasarkan pada pengalaman mistik. Lihat Mulyadi Kartanegara, Gerbang Kearifan, h. 44

${ }^{16}$ Suhrawardi, The Philosophy of Illumination, h. $21 .$.

${ }^{17}$ Berbeda dengan metode rasional, metode intuitif menangkap objek secara langsung atau immediate, namun objek-objek intuisi bersifat lebih abstrak, seperti rasa cinta, benci, kecewa, dan bahagia. Metode observasi (yang berkaitan dengan pengamatan indriawi), pada satu sisi, sama dengan metode intuitif, yakni sama-sama menangkap objeknya secara langsung, namun, objek-objek observasi itu berhubungan dengan objek-objek fisik. Pemikiran kaum Skeptis adalah meragukan segala sesuatu atau tidak meyakini setiap $\mathrm{h}$.

18Mulla Muhsin Fayd, Ușul al-Ma'ärif, h. 232.

${ }^{19}$ Tetapi dalam perkembangan filsafat pasca Ibn Rusyd, tasawuf semakin tidak bisa dipisahkan dari filsafat. Sebagaimana kita ketahui betapa Suhrawardi menganggap sangat penting, bahkan fundamental pengalaman mistik dalam dan bagi filsafatnya. Sementara itu seperti dikatakan Ibn Khaldun, baik teologi maupun tasawuf, pada masanya telah bercampur sedemikian rupa dengan persoalan-persoalan filsafat, sehingga menurutnya cukup sulit dibedakan.

20Mulyadi Kartanegara, Gerbang Kearifan, h. 56

${ }^{21}$ Muhyiddin Ibn 'Arabi, Fușūs al-Hikām, Syarh Janady, h. 8

22Ibn Arabi, Syarh al-Tajalliyah al-Ilāhiyah, h. 2, 3, dan 261

23Ibn Arabi, Futuhāt al-Makiyah, Jil. I, h. 288 dan 289, dan II, h. 66

${ }^{24}$ Ibn Arabi, Futuhāt al-Makiyah, jilid pertama, h. 213-214.

${ }^{25}$ Nama lengkap Mulla Șadrā adalah Șadr al-Dīn Syirāzī. Ia dilahirkan di Syirāz pada 979 H/1571 M dari keluarga Qawam yang terkenal dan terhormat. Mulla Șadrā membangun mazhab baru filsafat dengan sangat antusias dan semangat mempertemukan berbagai aliran yang berkembang dikalangan Muslim sebelumnya. Baca Murtadha Muthahhari, Pengantar Pemikiran Șadrā : Filsafat Hikmah, h. 13.

26Murtadha Muthahhari, Pengantar Pemikiran, h. 13.

${ }^{27}$ Seyyed Hossein Nasr, Mulla Sadrā: His Teaching, dalam Seyyed Hossein Nasr dan Oliver Leaman (ed), History ofIslamic Philosophy, VOl. II, London: Routledge, tth, h. 648

28Sayed Hossein Nasr, Ṣadr al-Dīn Shirāzī(Mulla Șadrā) dalam MM. Syarif (ed), A History of Muslim Philosophy, Vol. II, Weisbaden: Otto Harrassowitz, 1963, h. 943

${ }^{29}$ Haidar Bagir, Buku Saku Filsafat Islam, h. 173

30Mulla Șadrā, Asfar, Jil. III, h. 278 
${ }^{31}$ Konsep-konsep filosofis dan logikal itu disebut sebagai "kategori kedua yang dicerap oleh akal" (secondary intelligibles). Perbedaan keduanya adalah bahwa konsep-konsep kedua filosofis (philosophical secondary intelligibles) terabstraksi dari objek-objek eksternal dan sementara konsep-konsep kedua logikal (logical secondary intelligibles) terabstraksi dari objek-objek dalam pikiran. Mulla Sadra, Asfar, jilid pertama, h. 332, 333

${ }^{32}$ Dan begitu pula sebaliknya, suatu maujūd yang kuat dan sempurna maka pengungkapan dan pancaran wujudnya pun akan semakin kuat dan berada pada batas "kemestian" untuk bisa diindera oleh akal. Perlu diketahui bahwa batas "kemungkinan" dan "kemestian" untuk dicerap ini merupakan ungkapan derajat-derajat eksistensiMulla Sadra, Asfar, h. 335, 338, dan 339

${ }^{33}$ Lihat Risālah al-Tașawwur wa'l-Tașdīq, h. 308

${ }^{34}$ Lihat, Asfar, jilid pertama, h. 76, 263, 327, dan jilid ketiga, h. 280-309. al-Masāil al-Quddūsiyah, h. 33-72. Mafātih al-Ghaib, h. 101, 102. Risālah al-Tașawwur wa'l-Tașdīq, h. 308. Syarh al-Hidāyah, h. 222

35Mulla Sadra dalam hal ini, berupaya menganalisa secara teliti dan cermat persoalan tersebut dan memberikan solusi secara akurat, komprehensif, dan sempurna sedemikian sehingga tak menyisakan lagi hal yang perlu dibahas. Ia mengajukan metode baru dalam menyelesaikan persoalan tersebut dan sekaligus menyempurnakan argumentasi dan burhān yang dikonstruksi oleh Syaikh Isyraq. Ia berkata, "Ketika kita meraih suatu ilmu, maka sesuatu telah hadir dalam jiwa kita dimana hal itu tidak ada sebelumnya. Dan terdapat pengaruh yang berbeda antara kehadiran sesuatu tertentu dan kehadiran sesuatu yang lain dalam jiwa. Oleh sebab itu, pengaruh kehadiran sesuatu tertentu tidak lain karena kesesuaiannya dengan objek eksternalnya.

${ }^{36}$ Seyed Hossein Nasr, dalam pengantar buku Knowledge by Presence: Epistemology in Islamic Philosophy, karya Mehdi Ha'iri Yazdi, 1992. h. 23

37Ibnn Sina, Kitāb al-Najāh, h. 206.

38Thabathabai, Nihāyah al-Hikmah, h. 293-294

39Thabathabai, Nihāyah al-Hikmah..h. 298. Lihat juga Thabathabai, Bidāyah al-Hikmah, h. 173

40Thabathabai, Nihāyah al-Hikmah, h. 350. Lihat juga Thabathabai, Bidāyah al-Hikmah, h. 203

${ }^{41}$ Muhyiddin Ibn 'Arabi, Fușūṣ al-Hikam, Syarh Janady, h. 8

42Untuk menjelaskan dan menginterpretasi apa yang diketahui seseorang dengan jalan intuisi sangatlah memerlukan kepiawaian yang 
BAMBANG IRAWAN:Intuisi sebagai Sumber Pengetahuan

besar dalam berpikir, dan ini tidak akan bisa dicapai kecuali dengan latar belakang jerih payah berpikir dan analisis-analisis filosofis yang panjang. Jika tidak, maka seseorang yang mengalami intuisi akan terjebak pada penggunaan kata-kata yang ambigu sehingga bisa menjadi penyebab timbulnya kesesatan dan penyelewenangan. Baca John Renard, Knowledge of God in classical Sufism..h.326

${ }^{43}$ John Renard, Knowledge of God in classical Sufism, h. 326.

${ }^{44}$ Rumi, The Mathnawi of Jalal al-Din Rumi, terj. Reynold A. Nicholson, London: Luzac \& Co. Ltd, 1968.

${ }^{45}$ Hossen Ziai, Knowledge and Illumination, Atlanta:Georgia: Scholars Press, 1990, h. 37.

${ }^{46}$ Muhammad 'Utsman Najati, Jiwa dalam Pandangan Para Filosof Muslim, h. 16

${ }^{47}$ Hasan Zodeh Amuli, Ittiḥād 'aqil bi al-Ma'qūl, Qum; Intisyarate Qiyam, 1375, h. 169-172

${ }^{48}$ Muhammad 'Utsman Najati, Jiwa dalam Pandangan Para Filosof

Muslim..., h. 31

49Ibid., h. 75

50Ibid., h. 171-173

51Ibid., h. 285-286

52Muhammad Kamil al-Hurr, Ibn Sīnā: Hayātuhu wa Falsafatuhu, Beirūt: Dār al-Kutub al-'Ilmiyah, 1991), h. 10-15.

${ }^{53}$ Emanasi merupakan proses berpikirnya 'Aqil terhadap diri-Nya sebagai Ma'qul. Jelasnya karena berta'aqqul-Nya Allah tentang zat-Nya menjadi sebab pertama dari menjadinya alam semesta ini. Adapaun kapannya proses berpikir itu terjadi, ditegaskan oleh Ibn Sina sudah terjadi semenjak azali, sebagai keniscayaan menjadikan alam bersifat azali juga. Sehubungan dengan ini, menurut Harun Nasution, ta'aqqul Allah tentang zat-Nya merupakan ilmu bagi Allah tentang diri-Nya sendiri. Sedangkan ilmu itu merupakah qudrah-Nya untuk menciptakan segalanya. Dengan demikian, untuk menjadikan sesuatu itu tercipta, cukup bagi Tuhan hal itu menjadi pengetahuan-Nya

${ }^{54}$ Abdullah Fatimi Niya, Farjam-e 'Isyq, h. 77

55Muhammad al-Gazali, Ihya al-'Ulum, jilid pertama, h. 297

56Risālah Qusyairiyah, h. 117 dan 118, penerjemah: Furuzanfur

57Jalaluddin Hamayi, Maulawi Nameh, jilid pertama, h. 593.

58Mulla Șadrā , al-Hikmah al-Muta'alliyat Jilid I, Beirut: Dār Ihyā al-Turaś al-'Arabi, 1410, h. 264

59Ibn 'Arabi, Journey to the Lord of power (Risālah al-Anwār fi mā Yumnah Sahib al-Halwā min al-Asrār), New York: Inner Traditions International Ltd, 1981. 
BAMBANG IRAWAN:Intuisi sebagai Sumber Pengetahuan

${ }^{60}$ Farīd al-Dīn 'Atțār, Tażkirah al-Auliyā;: MuslimSaints and Mystics, London: Routledge \& Kegal Paul, 1966, h. 59.

${ }^{61}$ QS. Fushshilat: 53

62Mulla Husain Kasyani, Lub Libab Maśnawi, h. 393

${ }^{63}$ Abdullah Fatimi Niya, Farjame 'Isyq, h. 73

${ }^{64}$ Mulla Sadra, Asfar, Jil. IX, h. 136

${ }^{65}$ QS. Anfal [8]: 29.

${ }^{66} \mathrm{QS}$. 'Ankabūt [29]: 69

${ }^{67} \mathrm{QS}$. Hadīd [57]: 28

${ }^{68} \mathrm{Akal}$ manusia terbagi dua, akal teoritis dan praktis. 


\section{DAFTAR PUSTAKA}

Kartanegara, Mulyadi, Gerbang Kearifan: Sebuah Pengantar Filsafat Islam, Jakarta: Lentera Hati, 2006.

Kartanegara, Mulyadi, Integrasi Ilmu: Sebuah Rekonstruksi Holistik, Bandung: Mizan, 2005.

Kartanegara, Mulyadi, Menembus Batas Waktu: Panorama Filsafat Islam, Bandung: Mizan, 2002.

Kartanegara, Mulyadi, Mengislamkan Nalar: Sebuah Respon terhadap Modernitas, Jakarta: Erlangga, 2007.

Kartanegara, Mulyadi, Nalar Religius: Memahami Hakikat Tuhan, Alam, dan Manusia, Jakarta: Erlangga, 2007.

Keddie, Nikki R. , Roots of Revolution an Interpretative History of Modern Iran, Bimhangton: The Vail Balluo Press, 1981.

Keraf, A. Sonny dan Mikhael Dua, Ilmu Pengetahuan: Sebuah Tinjauan Filosofis, Yogyakarta: Kanisius, 2001.

Kuhn, Thomas, The Structure of Scientific Revolutions: Peran Paradigma dalam Revolusi Sains, Bandung: Remaja Rosdakarya, 2000.

Kuntowijoyo, Islam Sebagai Ilmu: Epistemologi, Metodologi, dan Etika, Yogyakarta: Tiara Waana, 2006.

Leaman, Oliver, Pengantar Filsafat Islam: Sebuah Pendekatan Tematis, Bandung: Mizan, 2001.

Madkour, Ibrahim, Aliran dan Teori Filsafat Islam, Jakarta: Bumi Aksara, 1995.

Madkour, Ibrahim, Filsafat Islam: Metode dan Penerapan, (terj. Yudian Wahyudi Asmin), Jakarta: RajaGrafindo Persada, 1993

Moeleong, Lexi J, Metodologi Penelitian Kualitatif, Bandung; Remaja Rosdakarya, 1997. 
BAMBANG IRAWAN:Intuisi sebagai Sumber Pengetahuan

Muchaddam, Achmad, Tuhan dalam Filsafat Thabathabai, Jakarta: Teraju, 2004

Muhadjir, Noeng, Metodologi Penelitian Kualitatif, Yogyakarta: Rake Sarasin, Edisi III, 1996.

Muhammad Alhamid Musa, Jalal, Manhaj al-Bahs $\mid$ al-'Ilm 'inda'l-'Arab, Beirut: Dar al-kutub al-Lubnani, 1972

Muthahhari, Murtadha, Pengantar Pemikiran Șadrā, Filsafat Hikmah, (terj. Tim Penerjemah Mizan), Bandung: Mizan, 2002.

Nasr, Seyyed Hossein, An Introduction to Islamic Cosmological Doctrines: Conception of Nature and Mthode Used for its Study by The Ikhwan al-Shafa, al-Bairuni and Ibn Sina, New Delhi: Shambala Boulder, 1970.

Nasr, Seyyed Hossein, Islam dan Nestafa Manusia Modern, terjemah Anas Mahyudin, Bandung: Pustaka.

Nasr, Seyyed Hossein, Islam Tradisi, terj. Lukman Hakim. Bandung;Pustaka, 1994.

Nasr, Seyyed Hossein, Man and Nature: The Spiritual Crisis of Modern Man, London: Mandala Book, 1976.

Nasr, Seyyed Hossein, Sadr al-Din Syirazi and His Transcendent Theosophy Tehran: 1978.

Nasr, Seyyed Hossein, Three Muslim Sage, Cambridge: Oxford University, 1970

Nasution, Harun, Falsafat Agama, Jakarta: Bulan Bintang, 1991.

Noer, Kautsar Azhari, Ibn 'Arabi: Wahdāt al-Wujūd dalam Perdebatan, Jakarta: Paramadina, 1996.

Notonagoro, "Azas-azas Filsafat", diktat, Yogyakarta: Yayasan Pembinaan Fakultas Filsafat UGM, 1969.

Omar Nassef, Abdullah (ed), Social and Natural Sciences, The Islamic perspective Ismael Raji al-Faruqi, Jeddah: King Abdul Aziz University, 1981. 
BAMBANG IRAWAN:Intuisi sebagai Sumber Pengetahuan

Pranarka, AMW. dan A. Bakker, Epistemologi, Kebudayaan dan Pendidikan, Yogyakarta: Kelompok Studi Filsafat, 1979.

Qadir, C.A, Philosophy and Science in the Islamic World, London: Routledge, 1990.

Qosim, Abul, "Corak Pemikiran Kalam Tafsir al-Mizan”, Surabaya: Tesis Program Pascasarjana IAIN Sunan Ampel Surabaya, 1999.

Rahman, Fazlur, Filsafat Șadrā (terj. Munir A. Muin), Bandung: Pustaka, 2000.

Rahman, Fazlur, The Philosophy of Mulla Sadra, Albany: State University of New York Press, 1975.

Razzaqi, "Abu al-Qasim Pengantar kepada Tafsir al-Mizan”, dalam Jurnal Studi-studi Al-Hikmah, Bandung: Yayasan Muthahhari.

Rumi, The Mathnawi of Jalal al-Din Rumi, terj. Reynold A. Nicholson, London: Luzac \& Co. Ltd, 1968.

Runes, Dagobert D, Dictionary of Philosophy, Totowa New Jersey: Adams \&Co, 1971.

Russel, Bertrand, Religion and Science, London: Oxford University Press, 1982.

Russel, Bertrand, Sejarah Filsafat Barat, Yogyakarta: Pustaka Pelajar, 2002.

S. Praja, Juhaya, Filsafat dan Metodologi Ilmu dalam Islam dan Penerapannya di Indonesia, Jakarta:Teraju, 2002.

Șadrā , Mulla, Kitāb al-Mashā’ir, ed., Henry Corbin, edisi ke-2, Tehran: 1984.

Saifuddin, Endang, Ilmu Filsafat dan Agama, Surabaya: Bina Ilmu, 1979.

Sardar, Ziauddin, Explorations in Islami Seines, New York: Suny, 1989.

Sardar, Ziauddin, Islamisasi Ilmu Pengetahuan atau westernisasi Islam dalam Jihad Intelektual, terj. Priyono, Surabaya: Risalah Gusti, 1998. 
BAMBANG IRAWAN:Intuisi sebagai Sumber Pengetahuan

Schuon, Frithjof, Understanding Islam, terj. D.M. Matheson, London: Unwin Paperbacks, 1981.

Shihab, Quraish, Membumikan Al-Qur'an, Bandung: Mizan,1992.

Sorous, Abdul Karim, Menggugat Otoritas dan Tradisi Agama,(terj. Abdullah Ali), Bandung: Mizan, 2002.

Suhrawardi, "Hiikmat al-Isyrāq" dalam Opera Metaphysica et Mystical, II, ed. Henry Corbin, Tehran: 1993.

Suhrawardi, "Talwihat" dalam Opera Metaphysica et Mystical, I, ed. Henry Corbin, Tehran: 1993.

Surajiyo, Filsafat Ilmu dan Perkembangannya di Indonesia, Jakarta: Bumi Aksara, 2007.

Suriasumantri, Jujun (ed.,) Ilmu dalam Perspektif, Jakarta: Yayasan Obor, 2001.

Suriasumantri, Jujun S, Filsafat Ilmu, Jakarta ; Sinar Harapan, 1985.

Susanto, Wildan, "Ruh dalam Pandangan Thabathabai, Studi atas Ayat tentang Ruh dalam Tafsir Mizan", Jakarta: Skripsi Fakultas Ushuluddin IAIN Syahid, 2000.

Syarif, M.M. (Ed.), A History of Muslim Philoshophy, Vol II, Wiesbaden: Otto Harrassowitz, 1963.

Syarif, MM (ed), A History of Muslim Philosophy, Vol. I, Weisbaden: Otto Harrassowitz, 1963.

Taqi Misbah Yazdi, Muhammad, Philosophycal Instructions, An Introduction to Contemporary Islamic Philosophy, New York: Global Publications, 1999.

Țabāțabāi, Muhammad Husain, al-Mīzān fi Tafsìr al-Qur'ān, Beirut: Mu'assasat al-'Alamiy li al-Mathbu'at, 1991

Ṭabāțabāi, Muhammad Husain, Bidāyah al-Hikmah, Qum: Mu'assasah al-Islami al-Thiba'ah li Jami'ah al-Mudarrisin, t.th. 
